\title{
Correction to: Genital Beautification and Rejuvenation with Combined Use of Surgical and Non-surgical Methods
}

\author{
Gaye Toplu $^{1} \cdot$ Dincer Altinel $^{1}$
}

Published online: 17 February 2021

(C) Springer Science+Business Media, LLC, part of Springer Nature and International Society of Aesthetic Plastic Surgery 2021

\section{Correction to:}

Aesth Plast Surg

https://doi.org/10.1007/s00266-020-01980-z

This article was updated to add references 31 and 32 and respective in text citations.
Publisher's Note Springer Nature remains neutral with regard to jurisdictional claims in published maps and institutional affiliations.

The original article can be found online at https://doi.org/10.1007/ s00266-020-01980-z.

\section{Gaye Toplu}

gayetoplu@gmail.com

1 Department of Plastic, Reconstructive and Aesthetic Surgery,

Univeristy of Health Sciences, Istanbul Training and

Research Hospital, Istanbul, Turkey 